\title{
Implementation Place of 'Uqubat Canings in Fiqh Perspective (Analysis of Aceh Governor Regulation Number 5 of 2018)
}

\author{
Helmi $^{1}$, Saiful Bahri ${ }^{1}$, Riyandi ${ }^{1}$, Nurazizah ${ }^{2}$, Nurmasyitah ${ }^{2}$ \\ ${ }^{1}$ Lecturer in Islamic Institute of Al-Aziziyah Samalanga, Bireun Aceh, Indonesia \\ ${ }^{2}$ Student in Islamic Institute of Al-Aziziyah Samalanga, Bireun Aceh, Indonesia \\ sihar@ecampus.ut.ac.id
}

\begin{abstract}
One form of the development of fiqh is to make the charge of fiqh in the form of theoretical laws into practical laws by putting them in the legislation of a certain State or territory in the State. After being granted the right to implement Islamic sharia by the State, Aceh as a provincial territory within the Unitary State of the Republic of Indonesia had the opportunity to realize fiqh laws into legislation termed Qanun, in order to regulate the behavior of its people to be under the auspices of sharia law. Throughout the course of the application of Islamic sharia based on various Qanun that was built, its implementation has never been separated from various problems and criticisms, both from the internal elements of Aceh, National and International. Among the cases that finally led to the problem was the birth of the Aceh PERGUB Number 5 of 2018. The problem that arose was a sharp criticism contents of some of the PERGUB contents which was deemed to deviate from the previous Qanun and deviated from the provisions of fiqh, even further claimed as an effort to dwarf the Islamic sharia. However, if examined objectively, it is not certain that the regulation will deviate from the existing Qanun and fiqh. But like a hot ball that is rolling, the debate that occurs in response to the PERGUB is sometimes no longer at the level of finding a solution, but it has led to things that are political.
\end{abstract}

Keywords: Ta'zir; caning; PERGUB; fiqh.

\section{Introduction}

Based on Law Number 44 of 1999 concerning the special features of Aceh and the Special Province of Aceh Province Qanun Number 5 of 2000 concerning the implementation of Islamic sharia, and also reinforced by Law Number 11 of 2006 concerning the Government of Aceh, for the first time in the reform era. The Government of Aceh implements Islamic kaffah under the auspices of the State constitution. In order to fulfill the mandate of the aforementioned laws, the Aceh government and the legislative body also formulated various Qanun on the implementation of Islamic sharia in Aceh more partially.

Among the Qanuns that were built were Nanggroe Aceh Darussalam Province Qanun Number 12 of 2003 concerning khamar drinks and other form, Qanun Number 13 of 2003 about maisir (gambling), and Qanun Number 14 of 2003 about khalwat (nasty). The essence of the three Qanun is to prohibit the consumption of liquor, gambling and nasty. In addition, it also stipulates sanctions in the form of caning of the perpetrators.

As for the implementation of 'uqubat (especially the place of its implementation), besides being regulated in the articles of the three Qanun, it is also regulated in Governor Regulation of Nanggroe Aceh Darussalam Province Number 10 of 2005 Article 4 paragraph (1) which reads "Uqubat caning is done in a place that can be seen by many people attended by the Public Prosecutor and the appointed doctor".

In addition to the three Qanun and Governor Regulations above, the place for implementing the uqubat caning is also regulated in Qanun Number 7 of 2013 concerning Jinayah Procedural Law. Furthermore, in 2018, the Aceh Governor issued Governor 
Regulation (PERGUB) Number 5 Regarding the Implementation of the Jinayah Procedure Law, which slightly modified the technical implementation of the Uqubat caning by translating the word "open place". In Article 30 paragraph (3) of the PERGUB referred to is stated "Open place as stated in paragraph (1) is located in a Correctional Institution / Detention Center / Detention Branch". ${ }^{\text {. }}$

The birth of PERGUB No. 5 of 2018 has raised the pros and cons among the people of Aceh, both from the political elite and ordinary people. These pros and cons are affected by the openness of democratic nature and the dynamics of community legal thinking that are sometimes subjective in addressing the background issues of the issuance of PERGUB. More than that, even some of the community's comments said that the contents of the PERGUB violated the existing Qanun and also did not comply with the provisions of Fiqh.

\section{Review of Literatures}

'Uqubat canings is a term translated from the word jald in Arabic. The meaning of the word jald in the context of punishment is hitting the skin with rattan. ${ }^{2}$ In the realm of jinayah fiqh, "uqubat canings is known as the "volume uqubat". Basically, the uqubat canings is enforced as a form of punishment for unmarried adulterers, drinkers, and those who accuse their wives or others of adultery. In addition, the uqubat caning can also be used as a form of punishment for crimes that are not regulated in the form of qishas and hudud. In this case, the uqubat canings is seen as a form of ta'zir punishment ${ }^{3}$, which is technically arranged in such a way as in jinayah fiqh.

\section{Discussion}

In Islam, the implementation of the uqubat canings is based on a strong and clear argument and philosophy. The following author presents both.

\subsection{Legal Basis 'Uqubat canings}

a. Al-Qur`an others are:

In the Qur'an there are several verses that stipulate the caning of criminals. Among

1) Surah al-Nur verse 2 :

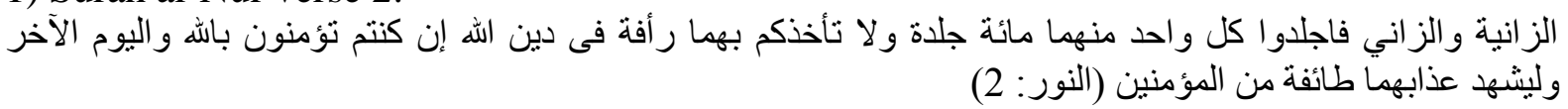

Meaning: The [unmarried] woman or [unmarried] man found guilty of sexual intercourse lash each one of them with a hundred lashes, and do not be taken by pity for them in the religion of Allah, if you should believe in Allah and the Last Day. And let a group of the believers witness their punishment. (al-Nur: 2)

\footnotetext{
1 https://jdih.acehprov.go.id.peraturangubernuraceh.pelaksanaanhukumacarajinayat//. Accessed on 02 October 2018

${ }^{2}$ Muhammad Idris 'Abd al-Ra uf al-Marbawi, Qamus Idris al-Marbawi; Arab-Melayu, Vol. I, Print. V, (Ttp: Dar Ihya' al-Kutub al-'Arabiyyah, tt), p. 105.

3 'Abd al-Qadir 'Audah, al-Tasyri' al-Jana i al-Islami Muqaranan bi al-Qanun al-Wadh'i, Vol. I, (Ttp: Mu`assasah alRisalah, tt), p. 689
} 
2) Surah al-Nur verse 4:

و الذين يرمون المحصنات ثم لم يأتوا بأربعة شهداء فجلدوهم ثمانين جلدة ولا تقبلو لهم شهادة أبدا و ألثلك هم الفاسقون

(النور: (4) (النين برن)

Meaning: And those who accuse chaste women and then do not produce four witnesses - lash them with eighty lashes and do not accept from them testimony ever after. And those are the defiantly disobedient, (al-Nur:4).

The first verse above explains the punishment of caning of adulterers, while the second verse describes the punishment of caning of those who accuse a good woman of adultery, while the accuser cannot bring witnesses. Thus, the two verses above discuss the caning as a form of hudud, not ta'zir.

b. Hadith

In addition to the verses of al-Qur'an, there are also some traditions which can be used as a basis for caning of criminals. Among others are:

1). Hadith of 'Ubadah ibn al-Shamit:

عن عبادة بن الصامت قال: قال رسول اله صلى الله عليه وسلم خذوا عني خذو ا عني فقد جعل الله لهن سبيلا, البكر بالبكر

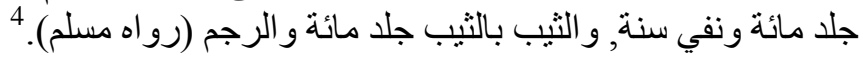

Meaning: Narrated from Ubadah ibn al-Shamit, he said that Rasulullah SAW said "understand from my deeds, understand from my deeds, verily Allah still sets rules against them (adulterers), for young men and virgins are punished with a hundred of canings and exiled during a hundred one year. For widows and widowers caning a hundred times and stoned". (H.R. Muslim).

2). Hadis Anas ibn Malik:

عن أنس بن مالك قال أول لعان كان فى الإسلام أن شريك بن سمحاء قذفه هلال بن أمية بامر أتها فقال لهاله النبي صلى الله

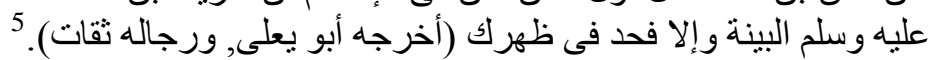

Meaning: Narrated from Anas ibn Malik, he said that the first occurrence of a li'an oath in Islam was when Hilal ibn Umayyah accused his wife of adultery with Sharik ibn Samha: Furthermore Rasulullah SAW said to Hilal ibn Umayyah "submit a witness, if not then the had will befall your body". (H.R. Abu Ya'la, All Narrators of Tsiqqah).

\subsection{Philosophical Basis of Enforcement Uqubat Canings}

Islam as a religion that brings mercy to all nature has teachings and rules of law which are always oriented to the benefit of humans. Every law that is prescribed must contain the value of benefits returned to humans, it's just that the value of benefits is sometimes not found after reasoning. But generally, in the applied laws can be found the value of benefits which is also called the wisdom of the law or the philosophical basis of law.

With regard to caning, in principle the sentence is carried out to give a deterrent effect on the perpetrators of criminal acts. Another thing to be achieved is to be able to prevent criminal acts or immoral acts and also as a means to achieve public benefit and protect it. The determined punishment is more preventive so people will refrain from doing that. A rule of

\footnotetext{
${ }^{4}$ Muslim ibn al-Hajjaj al-Naisaburi, Shahih Muslim, Vol. IV, (Beirut: Dar al-Fikr, 1994), p. 167

${ }^{5}$ Ibnu Hajar al-'Asqalani, Bulugh al-Maram..., p. 230
} 
law is usually not effective if it is limited to prohibiting, without strict sanctions. ${ }^{6}$ Therefore, the punishment stipulated in Islam is aimed at bringing humans under the auspices of the rule of law. Herein lies the benefit and justice which is the peak of the philosophical value of Islamic law, because with the realization of benefit and justice, human life will be peaceful and safe. With this, the presence of Islam can truly be felt as a blessing for all nature.

One example is the application of caning of adultery. As is known that adultery is an act that brings kemudharatan and threatens one element of Maqashid al-Sharia, namely hifzh al-nasb agreed in Islam to protect and protect it. Therefore, God establishes a very painful punishment for the culprit. Aside from being an equal retaliation against the perpetrators, the punishment is also able to make other people stop and not do it.

God incriminates the form of punishment for adulterers because he has committed grave sins and crimes that deviate from the norms of humanity and social life. ${ }^{7}$ While the lesson to be learned from the punishment for other than the perpetrators is so that people can make the punishment as an afterthought, where when his lust invites adultery, he will remember how painful the punishment will be received. This can prevent adultery. When people do not commit adultery, the goal of sharia is to take care of offspring.

\subsection{Uqubat Canings in the Law System in Aceh}

In carrying out its privileges in the field of religious life, Aceh has compiled various Qanun regarding the implementation of Islamic sharia. One of the cases regulated in the Qanun concerns sanctions in the form of caning of Islamic sharia violators. Next, the author presents the legal basis and mechanism for its implementation, as well as the contents of the PERGUB Aceh No. 5 concerning the implementation of caning.

\subsection{Legal Basis and Implementation Mechanism}

Caning of Islamic sharia violators is mentioned in several Qanuns. Among them Qanun Nanggroe Aceh Darussalam Province Number 11 Year 2002 concerning the Implementation of Islamic Sharia in the Field of Aqeedah, Worship and Shi'a Islam. In article 20 paragraph (1) it is stated "Whoever spreads heresy or heresy as referred to in article 5 paragraph (2) shall be sentenced to ta'zir in the form of a maximum prison sentence of 2 (two) years or a caning sentence in public at most 12 (twelve) times". Article 21 further states that "anyone who does not perform Friday prayers three times in a row without an elderly person as referred to in article 8 paragraph (1) shall be sentenced to ta'zir in the form of a maximum of 6 (six months) imprisonment or a caning in front general at most 3 (three) times. ${ }^{8}$

Caning is also listed in the Qanun of Nanggroe Aceh Darussalam Province Number 13 of 2003 concerning Maisir (gambling). Article 23 paragraph (1) states that "anyone who violates the provisions referred to in article 5, is threatened with" uqubat canings in public at most 12 (twelve) times and at least 6 (six) times. ${ }^{9}$ Furthermore, the Qanun of the Province of Nanggroe Aceh Darussalam No. 14 of 2003 concerning khalwat (Nasty) also stipulates caning. In article 22 paragraph (1) it is stated that "every person who violates the provisions

\footnotetext{
${ }^{6}$ Muslim Zainuddin, et al, Problematika Hukuman Cambuk di Aceh, Ed. I, (Banda Aceh: Dinas Syariat Islam Aceh, 2011), p. 14.

7 'Ali Ahmad al-Jurjawi, Hikmah al-Tasyri’ wa Falsafatuh, Vol. II, (Singapura-Jeddah: al-Haramain, tt), pp. 298-299

${ }^{8}$ Drafting team, Himpunan Undang-Undang..., p. 308.

${ }^{9}$ Drafting team, Himpunan Undang-Undang..., p. 343.
} 
as referred to in article 5, is threatened with 'uqubat ta'zir in the form of caning at the most 9 (nine) times, at least 3 (three) times and / or a maximum fine. Rp. 10. 000,000, - (ten million rupiah), and at least Rp. 2,500,000 (two million and five hundred thousand rupiah). ${ }^{10}$

Then the punishment in the form of caning was also mentioned in the Aceh Qanun Number 6 of 2014 concerning Jinayah Law. One of them in article 23 verse (1) states that "anyone who intentionally commits khalwat rahmah is threatened with 'uqubat ta'zir caning at most 10 (ten) times or a fine of at most one hundred (100) grams of pure gold or a maximum of 10 imprisonment" (ten) months ". In Chapter X which contains Concluding Provisions, article 74 states that at the time of this Qanun (Number 6 of 2014 concerning Jinayat Law), Qanun Number 12 of 2003 concerning khamar and the like, Qanun Number 13 of 2003 concerning Maisir, and Qanun Number 14 of 2003 concerning Seclusion is revoked and declared invalid. ${ }^{11}$

The revocation of the previous Qanun does not affect the implementation of caning of Islamic sharia violators in Aceh, because Qanun Number 6 of 2014 concerning Jinayah regulates the issue of caning in a more comprehensive manner without reducing the substance of the previous Qanun. If the previous Qanun did not mention whip punishment for homosexual, lesbian and ikhtilath perpetrators, then Qanun Number 6 of 2014 concerning Jinayah referred to it specifically. In essence, Qanun Number 6 of 2014 concerning Jinayah does not reduce or change the substance of the previous Qanun, but adds to the contents of the previous Qanun. Even if there are changes, such as caning of khalwat perpetrators who are threatened with 9 (nine) times of flagging according to article 22 paragraph (1) Qanun Number 14 of 2003, then add another flag so that it becomes ten times according to article 23 paragraph (1) Qanun Number 6 of 2014 concerning Jinayah. As such, the caning sentence in Aceh rests on a strong and clear legal basis.

In 2013, the Government of Aceh ratified Qanun Number 7 of 2013 concerning the Jinayah Procedural Law. This Qanun also regulates the mechanism for implementing the uqubat canings with a slight change as a form of improvement to the previous three Qanun. If in the previous three Qanun mentioned the place of "uqubat canings implementation globally without limiting the people present to witness the implementation, Qanun Number 7 of 2013 provides a few restrictions on this matter. For example, Qanun Number 7 of 2013 in article 262 paragraph (2) states "the implementation of the uqubat canings as referred to in paragraph (1) may not be attended by children under the age of 18 (eighteen) years". ${ }^{12}$

So, in substance, Qanun Number 7 of 2013 is a refinement of the previous three Qanun, especially related to the mechanism of 'uqubat canings implementation. Thus, if the implementation of 'uqubat canings is carried out in a place that is still classified as open, but cannot be witnessed by children under the age of eighteen, then this implementation does not deviate from the Qanun that governs it.

\subsection{The Content of Governor of Aceh Regulation Number 5 of 2018}

After going through various considerations, on 12 April 2018, the Governor of Aceh signed PERGUB Number 5 of 2018 concerning the Implementation of Jinayat Procedural Law. In general, this PERGUB contains procedural law relating to jinayat. Basically,

\footnotetext{
${ }^{10}$ Drafting team, Himpunan Undang-Undang..., p. 360.

11 www1-Media.acehprov.go.id.uploads. Accessed on 07 December 2018.

12 https//dsi.acehprov.go.id.uploads>2017/02. Accessed on 07 December 2018
} 
procedural law is a law enforcement mechanism. In positive law, these mechanisms and procedures are called criminal procedural law or criminal prosecution law. According to Kansil, criminal procedure law is a series of regulations on how to submit criminal cases to the court, and how judges impose sentences on the perpetrators of criminal acts, or a series of legal rules on how to preserve and maintain material criminal law. ${ }^{13}$

Islamic sharia Qanuns relating to crime are material laws that need to be maintained with a mechanism so that law enforcement can proceed. Therefore, the Qanuns require procedural law so that their contents can be upheld in a clear juridical frame. In Islamic criminal terms, procedural law is known as qanun al-murafa'at, or qanun al-ijra'at alqadha iyyah. ${ }^{14}$ Thus, the content of PERGUB Number 5 of 2018 is regarding the law enforcement procedures that have been listed in the Qanun about Jinayah Law.

One of the problems regulated in PERGUB Number 5 of 2018 is regarding the implementation of 'uqubat canings and 'uqubat fines. This is mentioned in article 30 . Following are complete excerpts from several verses of the article.

1) Uqubat caning is held in an open place and can be seen by those present;

2) Implementation of the uqubat caning as referred to in paragraph (1) may not be attended by children under the age of 18 (eighteen) years.

3) The open place referred to in paragraph (1) is located in the Correctional Institution / Detention Center / Detention Center;

4) Implementation of the uqubat caning in the Correctional Institution or Detention Center / Detention Center as referred to in paragraph (3) shall be carried out after the cooperation document exists between the Government of Aceh and the Regional Office of the Indonesian Ministry of Law and Human Rights.

5) Further provisions regarding the technical guidelines for implementing the uqubat caning in prisons / detention centers / detention branches are regulated in the cooperation text.

6) Prior to the existence of the cooperation document referred to in paragraph (4), the uqubat caning shall be carried out in another open place. ${ }^{15}$

Of the several verses above, the case that finally raises the pros and cons is the content of paragraph (3), which is when the word "open place" is meant by prison / detention / detention branch. The pros and cons of a new policy, of course, can be understood as a normal case in the realm of freedom of speech. But the problem is when an unpopular new policy is made by the political opponents of the policy maker as a means of bringing down the policy maker by leading public opinion as if the policy has deviated from existing rules, and is contrary to religious law.

As a result of these pros and cons it has dragged the people of Aceh at that time to berate the Governor through social media, without first studying the background of the birth of PERGUB, the contents of the Qanun Jinayah, and the law stipulated in fiqh regarding it. In giving birth to the PERGUB, the Governor of Aceh has its own philosophical basis. When interviewed by journalists, there were at least three reasons underlying the Governor of Aceh

\footnotetext{
${ }^{13}$ C.S.T. Kansil, Pengantar Ilmu Hukum dan Tata Hukum Indonesia, Print.VIII, (Jakarta: Balai Pustaka, 1986), p. 330

${ }_{14} \mathrm{Al}$ Yasa' Abubakar and Marah Halim, Hukum Pidana Islam di Nanggroe Aceh Darussalam, Ed. I, Print. II, (Banda Aceh: Dinas Syariat Islam NAD, 2007), p. 86.

15 https://jdih.acehprov.go.id.peraturangubernuraceh.pelaksanaanhukumacarajinayat//. Accessed on 02 October 2018
} 
in giving birth to this PERGUB. First, to reduce the protests that led to Islam phobia. Second, so as not to be witnessed by minors. Third, protect the psychology of the convicted person so that the sentence does not become a burden on his life in the future due to the freedom to record the process of caning carried out by those who witness it. ${ }^{16}$

The first reason given by the Governor was of course unacceptable, because he was impressed avoiding the negative impression of the implementation of caning from people who were not happy about the implementation of Islamic sharia, even though the Governor should provide an explanation to these parties about the importance of sharia enforcement ' at Islam for the benefit of the people, not exactly do an act that seems to comply with their tastes.

The second and third reasons can be found the truth side, although it needs to be studied in more depth about the political politics that underlie these two reasons. Regarding the second reason, namely the transfer of a caning to prison or detention can prevent children from watching it, this seems justified in order to maintain the psychology of children, although from the other side it is also necessary to be witnessed by children so that they are absorbed in their souls from an early age avoiding acts that violate religious provisions.

Regarding the third reason, it is also acceptable, because before the birth of the PERGUB, people who witnessed the caning process often perpetuated it by recording it on a cell phone, then the tape was disseminated on social media, and eventually it became viral in cyberspace. The existence of the recording on social media today is a burden for the person who was convicted and his family, because it could have been used by people who are not happy about it for the interests that could bring it down in the future, whereas people who punished it could have repented of his actions.

With the caning sentence being transferred to prison, this possibility can be avoided, because everyone who will go to prison to witness the process of caning will be asked to leave the device to record it. Thus, the second and third reasons can be accepted when looking at this side.

Regarding whether the transfer of caning to Lapas / Rutan / Rutan Branch violates the Qanun Jinayah principle, it is necessary to review the contents of the Qanun. When explored further, it seems that the PERGUB does not contradict existing Qanun. Some previous Qanun, namely Qanun Number 12 of 2003 concerning Khamar, Number 13 of 2003 concerning Maisir and Number 14 of 2003 concerning khalwat stated that 'Uqubat caning was carried out in a place that could be witnessed by many people in the presence of public prosecutors and appointed doctors.

The process of caning in prisons / detention centers / detention branches does not conflict with the three Qanun above because the process of caning in these three places can be witnessed by many people, only the number is limited and exclusive. Whereas if it is measured by Qanun Number 7 of 2013 concerning Jinayat Procedural Law, which states in article 262 paragraph (1) that "'uqubat caning is carried out in an open place and can be seen by those present", it is also still appropriate because the implementation of caning in Prisons / Detention Centers / Detention Centers are held openly and can be seen by those present.

\section{Conclusion}

16 https/ / Beritaterkini.co.news. Accessed on 07 December 2018 
The above description concludes that the regulations regarding the implementation of caning in Lapas, Rutan and Rutan branches as stipulated in Aceh PERGUB No. 5 of 2018, are not regulations that contradict Qanuns that govern them, nor are regulations that contradict fiqh. From the aspect of managing the way of social life in the current era of globalization for the better, the content of the PERGUB can even be seen as an advantage for the regularity of life and religion of Muslims in Aceh. This view is independent of the various political interests that underlie the birth of the intended PERGUB, but is merely an objective assessment by looking at the contents of the Qanun, PERGUB and fiqh.

\section{References}

'Abd al-Hamid al-Syarwani, Hasyiyah al-Syarwani 'ala Tuhfah al-Muhtaj, Vol. IX, Beirut: Dar al-Fikr, tt;

'Abd al-Qadir 'Audah, al-Tasyri' al-Jana i al-Islami Muqaranan bi al-Qanun al-Wadh'i, Vol. I, Ttp: Mu`assasah al-Risalah, tt;

Ahmad al-Shawi al-Maliki, Hasyiyah al-Shawi 'ala Tafsir al-Jalalain, Vol. III, Semarang: Toha Putera, tt;

'Ali Ahmad al-Jurjawi, Hikmah al-Tasyri' wa Falsafatuh, Jld. II, Singapura-Jeddah: alHaramain, $\mathrm{tt}$;

Al-Mawardi, Abi al-Hasan 'Ali ibn Muhammad, (2000) al-Ahkam al-Sulthaniyyah wa alWilayah al-Diniyyah, Tahqiq: Samir Mushthafa Rabab, Print. I, (Beirut: Maktabah al'Ashriyyah,

Al-Qurthubi, Abi 'Abd Allah Muhammad ibn Ahmad al-Anshari, (1993) al-Jami' li Ahkam al-Qur`an, Vol. VI, Beirut: Dar al-Kutub al-'Ilmiyyah.

Al-Syafi'i, Abi 'Abd Allah Muhammad ibn Idris, Tafsir al-Syafi'i, Jam'un wa Tahqiq wa Dirasah: Ahmad ibn Mushthafa al-Farran, Print. I, Riyadh: Dar al-Tadmuriyyah;

Al Yasa' Abubakar and Marah Halim, (2007) Hukum Pidana Islam di Nanggroe Aceh Darussalam, Ed. I, Print. II, Banda Aceh: Dinas Syariat Islam NAD.

'Athiyah al-Ajhuri, Hasyiyah 'ala al-Manzhumah al-Bayquniyyah fi Mushthalah al-Hadits, Semarang: Toha Putera, tt;

C.S.T. Kansil, (1986) Pengantar Ilmu Hukum dan Tata Hukum Indonesia, Print.VIII, Jakarta: Balai Pustaka.

https//Beritaterkini.co.news. (2018) Accessed on 07 December.

https//dsi.acehprov.go.id.uploads>2017/02. (2018) Accessed on 07 December.

https://jdih.acehprov.go.id.peraturangubernuraceh.pelaksanaanhukumacarajinayat//.(2018) Accessed on 02 October.

Ibnu Hajar al-'Asqalani, Ahmad ibn 'Ali, (2002) Bulugh al-Maram min Adillah al-Ahkam, Print. I, Jakarta: Dar al-Kutub al-Islamiyah.

Ibnu Katsir, (1986) Abi al-Fida' Isma'il ibn Katsir al-Qursyi, Tafsir Ibn Katsir, Vol. III, Mekkah: al-Maktabah al-Tijariyyah.

Muhammad 'Ali al-Sayis, Kulliyah al-Syari'ah Tafsir Ayat al-Ahkam, Vol. II, Ttp: Tp, tt;

Muhammad al-Khathib al-Syarbini, Mughni al-Muhtaj ila Ma'rifah Ma'ani Alfazh al-Minhaj, Vol. IV, Beirut: Dar al-Fikr, tt;

Muhammad Idris 'Abd al-Ra uf al-Marbawi, Qamus Idris al-Marbawi; Arab-Melayu, Vol. I, Print. V, Ttp: Dar Ihya` al-Kutub al-'Arabiyyah, tt; 
Muhammad Najib al-Muthi'i, (2001) Takmilah al-Majmu' Syarah al-Muhadzdzab, Vol. XXII, Print. I, Beirut: Dar Ihya` al-Turats al-'Arabi.

Muslim ibn al-Hajjaj al-Naisaburi, (1994) Shahih Muslim, Vol. IV, Beirut: Dar al-Fikr.

Muslim Zainuddin, et al. (2011) Problematika Hukuman Cambuk di Aceh, Ed. I, Banda Aceh: Dinas Syariat Islam Aceh.

Sulaiman al-Bujairimi, Hasyiyah al-Bujairimi 'ala Syarh Manhaj al-Thullab, Vol. IV, Beirut: Dar al-Fikr, tt;

Tim Penyusun, Himpunan Undang-Undang, Keputusan Presiden, Peraturan Daerah/Qanun, Intruksi Gubernur, Edaran Gubernur Berkaitan Pelaksanaan Syari'at Islam, Ed. VII, Banda Aceh: Dinas Syari'at Islam Aceh, 2009;

www1-Media.acehprov.go.id.uploads. Accessed on 07 December 2018;

Zakariyya al-Anshari, Syarh Manhaj al-Thullab, Vol. IV, Beirut: Dar al-Fikr, tt. 